Mid-American Review of Sociology

officer of the University of Nebraska to hold appointment specifically as a sociologist. More generally, the lectures illustrate the fusion of moralist and scientific themes in the Christian sociology typified by Ellwood (for further discussion of this latter point, see Ball's paper on "Howard's Institutional Sociology of Marriage and Family," elsewhere in this issue).

In 1899, Charles A. Ellwood completed his doctorate on "Some Prolegomena to Social Psychology" at the University of Chicago and accepted simultaneous appointments as Secretary of the Charity Organization Society of Lincoln, Nebraska, and as Lecturer (later, Instructor) in sociology at the University of Nebraska. During the year 1899-1900, Ellwood offered several sociology courses, for which he was not paid, as George E. Howard recounts -- elsewhere in this issue -- in his "History of Sociology in the University of Nebraska." Subsequently, Ellwood accepted an offer to become Professor of Sociology (with pay) at the University of Missouri.

For documentation of Ellwood's accomplishments, see Harry Elmer Barnes' two accounts. Specifically, "Charles Abram Ellwood Founder of Scientific Psychological Sociology," in Barnes' Intro duction to the History of Sociology, 1948, pp. 853-68; and Barnes' essay on Ellwood in the International Encyclopedia of the Social Sciences, vol. 5, 1968, pp. 31-33. Curiously, Barnes omits mention of Ellwood's first academic appointment and year in Nebraska in the latter article.

\section{THE STRANGER AT THE CURB}

\section{Mari Sandoz}

Lincoln, Nebraska

Mid-American Review of Sociology, 1988, Vol. XIII, No. 2:31-41

The velvet purr of the engine became even softer. The strange young man looked hopefully over his smart roadster at me, gave the slightest, most inconspicuous nod ahead. My hand moved vertically, a bare inch. The purr became a roar.

Once more, for the sixth time in as many blocks, Romance was repulsed. Or perhaps I only saved my arches.

And the parade of beckoning strangers at the curb is growing. Ten years ago it took some slight encouragement to get an offer of a pick-up on the sedate streets of Lincoln, Nebraska. Today it requires considerable sales resistance to slick cars and well-dressed soft-spoken young men to get home without taking at least one flier. ${ }^{2}$ Nor need you be a dewy-eyed Ziegfelder. A frank thirtiness not particularly redeemed by an under-fed, 'teenish body and a pinch of swank with your clothes will do. Not even a stack of omnibus volumes on your arm will discourage these avid companion seekers, ${ }^{3}$ by no means restricted to local talent. Among the 385 cars whose license plates I scrutinized during the last year were representatives from every state of the Union and three provinces of Canada.

I was not ready to accept the verdict of depravity passed upon the curber by the church and social workers and the good women of my acquaintance. Particularly when, on a Sunday evening stroll along the six blocks home from the city library with a ragged note book. under my arm, the curb seemed literally lined, every intersection blocked by hopefuls, I began to wonder. Who are these knights of the pavements and, as your great grandfather asked of your grandmother's boy friends, what are their intentions?

Why not interview them? I would at least get their "line" that way. I purchased a tiny blue notebook with an inch of pencil attached, pulled on my ône dress with" any air at all, lớoked" tó my lipstick, rehearsed a few questions and a pose or two before my slightly distorting mirror and took to the streets.

Copyright 1989 Mari Sandoz Estate

All Rights Reserved 
I asked the first 385 curbers who stopped me a set list of questions that might or might not be revealing but were undeniably impertinent. ${ }^{4}$ Upon me answers I succeeded in extracting, his probable age, the make, type, and antiquity of his car, and the state ing, his probable age, the make, the in which it was licensed. All this with my tongue in meth as others of proficiency must be some liars of many years marriage as well as others of proficiency among the lot. Even the car might well be the Old Man's, the wife's, or even the mother-in-law's.

A glance at the compilement of the data so collected shows the man at A to the popular to sixty, varies $\mathrm{Al}$ Capone. He reads everything from the struggling literary conception of Al Capone. He reads everything from the srog Chick Sales magazines to the pulps and the confessionals; everybody from Chick Sales to D.H. Lawrence and Sigrid Undset, even Chaucer, although I suspect that to D.H. Lawrence and hurled at my head, with one of the coarser lines from "Canterbury Tales," to confound me in my ignorance. ' The by-this-time less hopeful victims generally admitted that they enjoyed movies, anything from "Strangers May Kiss," to "Dr. Caligari," with some haziness about wher (he Dietrich the Doctor was seen. The curber lidols, parwoman) Ruth Chatterton and Marie Dressler; dicularly John Gilbert and Buddy Rogers, but how he goes in for the gumchewing Will!'

Singing is popular with these men, radio, canned, or face to face. They 't seem to care particularly whether it's Tetrazzini, an older gentleman insisted that his uncle was one of her accompanists, or Al Jolson -- anyone except Rudy Vallee. ${ }^{10}$

By profession this irrepressible optimist at the curb may be a ditch digger with muddy knees, a salesman unavoidably stranded over the weekend in a blue Sunday town, ${ }^{11}$ a pink-cheeked college boy, or a Ph.D. with end in a bives any kind of from a new golden key swung conspicuously. He drives any ke is for, against, and midget to a junked dreadnaught of ancient vintage. He is for, against, and on the fence of any public issue. He talks like a heist guy from a barber shop magazine or a delegate to a purists' convention. He drinks wet, dry, or dampish and probably votes the opposite.. He is or pretends to be ultrasentimental about his mother and often is about the girl he hopes to marry sentiment wait until the present incumbent vacates his some day, even if he must wat expects to find his Princess Beautiful waiting kitchen. Somehow he actually expects to He believes in Romantic Love, the at the curb, at least his temporary P.B. He believes in first sight but not in alimony.

Convinced that man is not so much himself when he is pursuing the wherewithal of his beer and pretzels or the native equivalents as when the whisle has blown and he must devise amusement for himself, I delved into What does he do with the much the curbers lauded American leisure? What does he like in reading matter, shows music, sports? What are his opinions or what pass for opinions, on such subjects as: married women working outside of the home, companionate marriage, divorce, alimony? What about war and prohibition? I soon learned to leave the Eighteenth Amendment to the last. It almost invariably terminated the party.

Specifically, what sort is the curber? Of the 385 men I questioned, 32 appeared to be under twenty; 236 between 20 and 30; 71 between 30 and 40; 23 between 40 and 50; 17 between 50 and 60; and 6 over that sometimes sedate age. They drove a variety of cars from the imported vehicle of the Oklahoma oil Indian (probably laid up for fuel now) to the slogan bespattered old wagon of a college freshman. One hundred twenty-seven had large cars, sixes and eights, late models; 62 old models of smaller cars.

While some of the men seemed informed in the book world, most of them expressed a preference for magazines. "You can lay 'em down," one told me. Many named two or more favorites among the periodicals. Thirtytwo read what I listed as the Literary group exclusively, seven of them Harper's Magazine; 200 preferred the popular monthlies and weeklies; 92 the pulps; 39 fraternal; 14 radical; 14 their wives' favorites; and 11 read religious periodicals. Eight mentioned obscure or made-up titles; 14 admitted or boasted that they never read and 25 departed when they didn't get immediate action on their invitation to "hop in." "Which ones are you selling?" asked a shrewd-eyed youth, mistaking my blue portable typewriter that I happened to be lugging home from the repair man for a canvasser's case.

In music the taste seemed to run to jazz, as might be expected by a woman perched on the curb, -- followed by sentimental songs of home love, and so on. Twenty-three sheepishly or defiantly said they liked classical. One third of the lot preferred dance music and wanted to go somewhere to indulge in their favorite pasttime. Twenty-nine departed in suspicion or disgust without registering a vote.

Ninety-six of the men approved companionate marriage but from their replies I suspected that few have more than a hazy notion of the Lindsey social panacea, ${ }^{12}$ evidently considering it trial marriage "without benefit." Thirty-six considered the discussion of such things with a strange woman immoral and let me know it; 47 didn't know what they thought, had other things in mind; 171 believed in divorce; 31 sometimes; 51 never; but-22 of the latter added that extreme measures were sometimes necessary; 107 approved of alimony; 63 only if there were children; 32 considered alimony woman's graft; and 48 believed that each case might be a law unto itself. Four declared emphatically that the state should care for the children if no responsible grandparents or what-not could or would take charge of them, although I had no lead question on the subject.

About the working wife, 133 said flatly no; 51 sometimes; 64 "if they want to;" 16 saw the solution of the alimony question through the employed woman; and three denied that they would expect a woman to give up a career that had cost her much time and effort for a mere incident like marriage. Two of these were of the four who believed that the state might better care for children of couples who go their various ways.

It may be significant that not one curber became impatient while these 
problems were being discussed. Perhaps they still hoped that I might take a flier.

Sports was also a good conversational topic, with the great national game preferred.

Political discussion the curber rebelled against, but he was perfectly ready to talk so long as I listened. Several spouted interminably just before election when the Grocer Norris case was occupying Senator Nye in our city. ${ }^{13}$ One hundred forty-seven boasted of republican leanings; 86 voted for the man; 73 admitted they were democrats; 20 didn't care for the graft in any form; 30 boasted of socialistic or communistic leanings, mild and virulent; 74 believed the results were the same no matter how you voted. Seven, probably more, I was always suspected of being connected with the police department, anticipated a millennium ushered in by force. One started a grand harangue on the subject, stopped at my evident amusement.

"You damned spy!" he sneered, and was gone. I was sorry about that and cultivated a bored exterior in the future.

The pressing public problem, after this inquisition, was almost a total washout. Either the curber doesn't see any or too many. Fifty-seven were sure that it was prohibition or the lack of it; 49 the various manifestations of the depression; 21 farm relief; 20 unemployment, not temporary, but through the machine; 67 couldn't agree on anything and scattered themselves from "showing some appreciation for what the A.E.F." done for 'em" to keeping birth control information out of the hands of high school students. One oldish gentleman lamented the passing of the licensed houses. "Women will never be safe on our streets until them places is brought back." One hundred twenty-six hadn't even a vague idea of anything more pressing than finding a woman. And by that time 121 had departed.

Prohibition dispersed most of the rest. ${ }^{\text {is }}$ Either they suspected me of being an agent for bootleggers and tried to tell me a good story they got from a salesman down the line or for a police spy and abused me. Ninety responded as they probably thought was expected by offering me a drink. Seventy-six asked me to put them in touch with something; 27 read me rhetorical lectures on drinking, particularly by women; 12 showed flasks or bottles by way of additional enticement; at least 82, perhaps more, I got cagey after a disagreeable incident or two and kept my distance, had been drinking. Not one gave a clear answer whether he favored prohibition or not.

But interviews, even though they be vastly more ego-searching than mine, can serve as little more than spring boards into theory compared to actual experiences. I recall an acquaintance who met a rather well-to-do man at the curb and married him, attaining thereby a social position she never could have hoped to attain unless given to reading the Cinderella magazines. Then there was the pretty little blond who lived down the hall from my room. One moming at three she pounded at my door, incoherent, hysterical, her clothing torn, her feet puffed over her absurd pumps from long distance hiking home from a ride with a slick-looking stranger in a big car. Fortunately she had been reared in a family of boys, knew something of boxing and was surprisingly able to look after herself. Which raises the question: Should girls be trained in close-quarter pugilism, say in junior high school? Even so, the man might be really determined.

Another case, more serious, comes to mind. Not so long ago a girl, still in her 'teens, was found tied to a tree by some early fishermen in a woods not far from Lincoln. She couldn't remember her name, had lost the power of speech. Only after long months of sympathetic care did she recover sufficiently to take up her work again. And all because she picked up a ride with a stranger one rainy evening when her bus was late.

But only the spectacular incidents become generally known. Most of the 385 indicated, with varying sincerity perhaps, that they "could treat woman like she wants to be treated." "You set your own pace," one generously offered. Another tried to give me money, saying, "You look like you had a good mother somewhere; go back to her." Most of them openly confessed that they were "good guys." After looking the lot over, I am inclined to agree with them. Only three of the 385 struck me as actually dangerous to a self-possessed young woman. Some of them carried the usual marks of success as the world measures that commodity. At a banquet of professional men I was placed beside a man who had been peculiarly bald and persistent in his approach the night before. He was an out-of-town man in excellent standing in his profession. It was funny. He alibied so hard to keep me from being sure. He had just come to town. People wer always taking someone else for him. Why, in Cleveland once .....

Then there was the much-lauded brother of a new acquaintance of mine. He came forward to meet his sister's new friend. Half way across the room he recognized me. His feet stammered; his smile wilted; he retreated, leaving my hand dangling. The little redhead he had once put in her place with such stinging sarcasm for asking questions that had no connection with her apparent profession invading this, his ancestral home! The sister apologized. It was all very unusual, she murmured. I'm sure of that. His type of curb affairs had better be kept far from his home.

Because Lincoln is a college town with no Sunday shows, students help swell the Sabbath crowd of hopefuls. Timid the first year, they become typical Jack Oakie -wise-crackers before they - sze finally turned loose, with or without the red leather-bound evidence of fairly successful professor spoofing.

While associate editor on an educational magazine, ${ }^{16} \mathrm{I}$ interviewed many out-of-state educators. Among these was one, who, judging by his photographs, was still young, but already nationally known and high up on the staff of an eastern school of education. The evening before the interview I went to the city library for such low down on the man as I could gather. At an intersection a car stopped directly in my path. A low voice asked politely, "May I see you home?" I looked up, into the face of the man whose pet egotisms I had just culled from Who's Who.

But not all of my curb experiences were pleasant or amusing. That alone would indicate that the curbers are exceptional. There was the one who stalled me the second time, unintentionally. "It's that --..- Question 
Mark again!" he snarled and crashed his gears getting away. Another apparently set the stage for his second attempt; showed me his bankbook with an impressive set of figures, gave me a list of his business connections well peppered with vice presidencies, called my attention to his heavy ring. "Ignorant fly-up-the-creek!" he called me when I failed to appreciate the lodge connections.

The wise-cracking youths can be cutting too. One christened me a "redheaded, hardboiled, frigidaire mama."

If I had hoped to keep clear of women I failed. One man confided to me that he was out giving his wife divorce "evidence." It sounds phoney now but for once I moved on first. Then there was the wife who shadowed her husband. Coincidence would have it that she see me talking to him. He had ideas on prohibition enforcement and craved a listener. But his wife didn't seem to know that. She followed me home; stopped me at the door.

"I'll have words with you -- you home wrecker!"

Over a cup of tea I gave her some advice which wasn't any good to me anyway -- not having a husband.

Even Romance knocked, although very timidly, during this study of the seeking male at the curb. ${ }^{17}$ The first day of the 1930 state fair, on my way home from the bakery across the street with a hot pie in my hand, a long, blue-green car blocked my path. I looked up. A liveried white man was at the wheel and in the back, shut off by one of those glass social barriers, was an astonishingly handsome Indian, dressed in perfect greys. He tipped his hat most courteously, smiled one of the astonishingly white smiles of that race and asked me to go to the fair with him. I regretted, but was intrigued by the chauffeur's perfect impersonality.

"He is a fine fella," the quick-witted Indian assured me, noting my glance, "but if you don't like, I drive myself."

I still regretted. Politely the man expressed his sorrow at my evident misunderstanding of his intentions. The car moved on. I saw the license plate. Oklahoma. An oil Indian!

Sometimes the most disarming situations are the most dangerous. A nice appearing young chap in his early twenties came over to a window where I was admiring a display of etchings. He made an intelligent comment or two. Why, yes, he would tell me anything I wanted to know, "Only let's not stand up." When he finally gave up trying to inveigle me into the car, a most desperate looking ruffian arose out of the back seat, slipped under the wheel and away they tore. Thrills, thrills! Almost I was taken for a ride!

A few days later a young man, not over twenty, blondly handsome in a pugilistic sort of way, stopped me by driving his long, impressive roadster across the walk at an alley. I stood back what I considered a safe distance and began. When he grasped that my interest was purely intellectual, he leaped for my wrist and pulled. His grip was like a grapple hook. The car started ahead. For once in my life my wits clicked. I whistled -- just as I would have out on the ranch to call our hunting dogs. ${ }^{18}$ For a split second the man hesitated. Then he dropped me off the running board and was gone, roaring through the quiet street. A Virginia car -- from the stronghold
of American chivalry!

If the curber was not too timid, too greatly pressed, or, shall I say, not too discriminating, he remained long enough to talk to his dreams. One wanted to be an organist with so powerful a touch that his listeners would bow before his music as the faithful towards Mecca. He sold real estate. Another believed that he might have built huge dams like the Hoover. He wouldn't say what he did. Judging by huge dams like the Hoover. He clerking or barbering he did. Judging by his bleached skin I should judge clerking or barbering. But sooner or later they all remembered the situation or perhaps that Lincoln seems to have an ordinance, and departed. Even so they were usually polite, always less bald, even at the worst, than the few of their kind who haunted the streets of even at the worst, than the few drive better cars now, the streets of Lincoln a few years ago. They drive better cars now, wear better clothes, have probably more to lose interesecution or scandal. Like him or not, the man who blocks the

Here, then, making stay until a less formal approach is devised. unrevealed as, making due allowance for the spoofers, who are not so unrevealed as they might suppose, is something of a cross-section of Lincoln's quicksilver population or at least the faction that was attracted to me. I find them surprisingly like the mill run of men I meet at the homes of my less discriminating lo homes of my less discriminating friends and surely there are many women and girls in town who would be glad to help them pass a lonely evening now between for the sexes, so far neither nature or society has made any provision for the growing isolation of the urban individual. Perhaps pick-ups are the modern substitute for the cave man's club, patently impractical now. Few men would be physically capable of dragging a woman home if they could find one with sufficient length of hair. Besides there is a scarcity of timber
for clubs.

With the automobile, however, a man can, unless the depression has hit him too hard, ${ }^{19}$ drive out so far, if he's a meany, that his captive's heels and mad money won' morning. morning. But first he must catch the woman, and therefore he slithers up to workers,- and beckons, in defiance of the city fathers, the church, the social

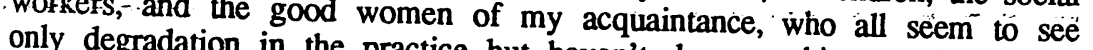
only degradation in the practice but haven't done anything much about it except elevate hands and eyebrows.

Which reminds me -- I must have my heels built up.

\section{EDITORIAL NOTES BY MICHAEL R HIL}

1.

"The Stranger at the Curb" was written by Sandoz in late 1930 (and completed no later than January 1931) following four years of intermittent field work in Lincoln, Nebraska. Publication of this heretofore unpublished sociological study by one of Nebraska's celebrated intellects was made possible through the generous assistance and permission of Caroline Sandoz Pifer on behalf of the
Mari Sandoz estate. 
The origins of Mari Sandoz' study are revealed in correspondence with several publishers to whom she tried, unsuccessfully, to sell her report as a commercial magazine article. She wrote to the editor of the Delineator in January 1931:

Four years ago, while I was conducting a couple of nationwide questionnaires for the School Executives Magazine and had just finished a very provocative course in sociology at the University, I began questioning those people who slither, usually unobtrusively, up to the curb and invite you into their particular brand of vehicle .... By spurts I kept this strategy going until November 1930 -- until I had 385 bits of paper with odd scribblings upon them. Then I compiled the results and this article, THE STRANGER AT THE CURB, is the result. (Sandoz to Graeve, 31 January 1931, Correspondence Box 1, Mari Sandoz Collection, University of Nebraska Archives, Lincoln, Nebraska; hereafter, "Sandoz Collection").

For H.L. Mencken, editor of American Mercury, Sandoz identified the specific intellectual roots of her study in the Nebraska sociology of Joyce O. Hertzler:

After taking a very provocative course in social progress under Dr. Hertzler of the University of Nebraska, I began to wonder about the growing curb pick-ups in Lincoln. (Sandoz to Mencken, 24 June 1931, Sandoz Collection).

Hertzler published Social Progress: A Theoretical Survey and Analysis in 1928, and no doubt found expressed its themes in his lectures at the University of Nebraska. In particular, Hertzler's discussion of changes in "Public Opinion" (pp. 245-268) and "The Domestic and Sexual Aspects of Progress" (pp. 435-460) prefigure themes explored in Sandoz' curbside interviews. Hertzler's emphasis on social "change forms the intellectual backdrop against which Sandoz hypothesized, "Surely not all these apparently very ordinary men could be evil-intentioned, not even by my grandmother's most tight-lipped definition" (Sandoz to Mencken, op. cit.) Focus on needed social adjustments also marked her conclusion:

And under it all runs one strain -- desire for a congenial companion. In immorality? Yes, but not so frequently as I had supposed. They seem ready enough to do whatever is expected of them -- and how they want someone to listen to them! There are so few ways of meeting the other sex in a city. Something ought to be done about it. (Sandoz to Editorial Offices, Liberty, 16 August 1930, Sandoz Collection).
For further analysis of Sandoz' sociological perspective, see Michael R. Hill (1987), "Novels, Thought Experiments, and Humanist Sociology in the Classroom: Mari Sandoz and Capital City," Teaching Sociology 15: 38-44; and Michael R. Hill (1989), "Mari Sandoz' Sociological Imagination: Capital City as an Ideal Type," Platte Valley Review. The standard biography of Sandoz' life and literary work is Helen Winter Stauffer (1982), Mari Sandoz: Story Catcher of the Plains.

2.

For more recent insight on the dynamics of "pick ups," see Mary Jo Deegan (1972), "The Meat Market Ritual," Society: 2:11; and her detailed analysis of "The Meet/Meat Market Ritual" in Mary Jo Deegan (1989), American Ritual Dramas: Social Rules and Cultural Meanings. Important structural aspects of male/female interactions are theoretically articulated in Erving Goffman's "The Arrangement between the Sexes," reprinted in Mary Jo Deegan and Michael R. Hill (1987), Women and Symbolic Interaction. Oppressive features of "male gauntlets" through which women must frequently travel are analyzed in Michael R. Hill and Mary Jo Deegan (1982), "The Female Tourist in a Male Landscape," CELA Forum (Council of Educators in Landscape Architecture) 1(2): 25-29; and further explored by Mary Jo Deegan in "The Female Pedestrian," forthcoming in Man-Environment Systems.

3. Sandoz' library reading at the time included John Cowper Powys (1929), The Meaning of Culture (Sandoz to Chenery, 4 August 1930, Sandoz Collection).

4. On method, Sandoz reported, "I ooze curbward at the sound of a brake or a more decorous signal, primed with a set of questions .... Sports, music, food, political leanings, farm relief, woman's sphere, and prohibition, all bring out vast differences and often argumentative oratory" (Sandoz to Chenery, op. cit.).

5. As to the number of interviews possible per trip, Sandoz wrote, "I gather three to ten scalps a trip, depending on the weather. More if it's a rainy Sunday evening. Lincoln is a no-Sunday show town .... I take the- reactions verbatim slang and all" (Sandoz to Chenery, op. cit.).

6. Sandoz noted, "And what a variety of tastes and culture is repre sented! One might almost say that these men represent a crosssection of the American Male" (Sandoz to Chenery, op. cit.).

7. "Chick Sales" was Charles (Chic) Sale (1885-1936), a vaudeville and film actor from South Dakota, self-styled as "America's great rural character actor," and author of two small books, The Specialist (1929), about a carpenter who built privys; and I'll Tell You Why (1930). Sigrid Undset (1882-1949), a Norwegian author, wrote a major trilogy, Kristin Lavransdatter (1920-1927), and won the 
Nobel Prize for Literature in 1928. The English novelist D.H Lawrence (1885-1930) authored the controversial Lady Chatterley's Lover (1928). Sandoz further observed, "In reading tastes they [the curbers] vary from Menckenites to Wild Westemers. Collier's is very popular with this flotsam .... Even Edith Wharton has been mentioned as a favorite author ...." (Sandoz to Chenery, op. cit.). When writing to the editor of Liberty magazine, she noted that Liberty was popular among the curbers and that Henry James helped anchor one end of the literary spectrum (Sandoz to Editorial Offices, Liberty, op. cit.).

8. "The Cabinet of Dr. Caligari" is a well-known example of German Expressionist film from 1920. "Strangers May Kiss" was produced by Metro Goldwyn Mayer.

9. Greta Garbo (b. 1905), Academy Award nominee for "Anna Christie" and "Romance" in 1930, for "Camille" in 1937; and "Ninotchka" in 1939. Marlene Dietrich (b. 1901), Academy Award nominee for "Morocco" in 1931. Her well-known films included "The Blue Angel" (1930). Ruth Chatterton (1893-1961), Academy Award nominee for "Madame X" in 1929; and "Sarah and Son" in 1930. Marie Dressler (1869-1934) won the Academy Award for Best Actress in "Min and Bill" in 1931. John Gilbert (1897-1936) appeared in such films as "Masks of the Devil" (1928); "A Woman of Affairs" (1929); "Way for a Sailor" (1930); and "Phantom of Paris" (1931). Charles "Buddy" Rogers (b. 1904) appeared in "Heads Up;" "My Best Girl;" "Red Lips;" "River of Romance," etc. Will Rogers (1879-1935), well-known American humorist, appeared in such films as "They Had to See Paris" (1929); "Happy Days" (1930); and "A Connecticut Yankee" (1931).

10. Luisa Tetrazzini (1874-1940) was an "Italian prima donna, voluminous of torso and mighty of lungs, who could pick up a carnation from a bouquet on the floor while singing a high $\mathrm{C}$ without losing power, and whose turbulent life story included a provisional marriage to a professional gigolo" (Nicholas Slonimsky, Music Since 1900. 4th ed. New York: Charles Scribner's Sons, 1971, p. 712) Al Jolson (1888-1950), an American vaudeville blackface minstrel singer who made the transition to film in the first "talking" motion pictures, appeared in "The Jazz Singer" (1928) and "The Singing Fool" (1928). Rudy Vallee (b. 1901), popular American singer, was the "prototypical protagonist of the fine art of crooning" (Slonimsky, op. cit., p. 19).

11. Cf., David N. Laband and D.H. Heinbuch (1987), Blue Laws: The History, Economics, and Politics of Sunday-Closing Laws.

12. Lindsey, a Denver judge, advocated permitting "no-fault" divorce for childless couples who wished to separate. Cf., Ben B. Lindsey; and W. Evans (1927), The Companionate Marriage.

13. When George W. Norris man for re-election as governor of Nebras$\mathrm{ka}$ in 1930, his opponents attempted to confuse the balloting by running another candidate, a grocer from Broken Bow with the same name, i.e., George W. Norris. After much controversy, the scheme was defeated in the courts After much controversy, the Nebraska, 1950, p. 304)

14. American Expeditionary Force, i.e the US. Armed Forces patched to Europe during World War I

15. Prohibition

example was an active concern among sociologists. See for in Social Causation in Social Causation," American Journal of Sociology 24: 61-80. In tion violations Herbert Hoover's concern over widespread prohibiand Enforcem lo the National Commission on Law Observance sioner and to which which Roscoe Pound served as a commissioner, and to which numerous sociologists, including Edith Abbott and Hattie Plum Williams, made substantial investigatory contribu-

16.

Sandoz was associate editor of School Executives Magazine from 1927 to 1929. Her name appears on the journal's masthead as Marie Macumber (her married name) from February 1929 (Vol. 48, No. 6) to September 1929 (Vol. 49, No. 1).

17. Sandoz reported, "Only once in the 380 interviews, to date, did I actually feel tempted to get into the car -- with a homely man who waxed eloquent upon Joseph Conrad" (Sandoz to Editorial man who Liberty, op. cit.)

18. For an account of Mari Sandoz' rough and ready childhood in the Nebraska sandhills, see her award-winning biography of her father,
Old Jules. (1935).

19. Mari Sandoz' empirically-documented sociological novel, Capital City (1939) is an insightful account of the depression era in the Great Plains. 